\title{
Discussion on the Application of Modern Information Technology in the Classroom Teaching of Economics and Management in Local Application-Oriented Colleges and Universities*
}

\author{
Liqiang Zhai \\ School of Economics and Management \\ Heihe University \\ Heihe, China
}

\author{
Xiaowan Wang \\ School of Economics and Management \\ Heihe University \\ Heihe, China
}

\author{
Nannan Jiang \\ School of Economics and Management \\ Heihe University \\ Heihe, China
}

\begin{abstract}
With the rapid development of modern information technology such as Internet and big data with computer network as the core, this brings new opportunities and challenges to the high-quality development of higher education in China. This paper starts with the classroom teaching of Economics and Management specialty in local applicationoriented colleges and universities, to explore the application of modern information technology in enriching classroom resources and expanding teaching methods, and how to promote the deep integration of modern information technology and classroom teaching.
\end{abstract}

Keywords-modern information technology; economic management; classroom teaching

\section{INTRODUCTION}

In recent years, with the rapid development of information technology, the integration process of information technology and higher education has been accelerating, and more and more modern information technology is used to assist classroom teaching and improve the quality of classroom teaching. The wide application of modern information technology in education and teaching has effectively promoted a new round of higher education teaching reform, and promoted a series of changes in classroom teaching mode, student learning style, teacher and student role, teaching

*Fund: This paper is a research project on higher education teaching reform in Heilongjiang Province in 2018, Research on Collaborative Innovation Training Mechanism of Applied Innovation Talents of economic and trade cooperation with Russia in Universities in Heilongiiang Province during the Construction of "One Belt and One Road" (Project No.: SJGY20180347) and the 2018 Heilongjiang University Student Innovation and Entrepreneurship Training Program: the phased research results of the Russian Business Intelligence Learning Practice Platform Project (Project No.: 201813744011). management mode, and curriculum construction methods. Local application-oriented colleges and universities should combine the characteristics of Economics and Management specialty, use modern information technology to expand teaching time and space, enhance the attraction of teaching, stimulate students' enthusiasm and autonomy of learning, and gradually explore the organic integration of modern information technology and classroom teaching mode of Economics and Management specialty to improve the quality of classroom teaching, and promote the reform of talent training mode with classroom teaching mode innovation, and improve the quality of applied professional talents in Economics and Management specialty. This paper is based on the reform of the classroom teaching mode of Economics and Management specialty of the local application-oriented colleges and universities and the application status of modern information technology, to explore the realistic path of promoting the deep integration of modern information technology and classroom teaching of Economics and Management specialty.

\section{The COMMON Practice OF INTEGRATING MODERN} INFORMATION TECHNOLOGY INTO THE CLASSROOM TEACHING OF ECONOMY AND MANAGEMENT

First is to do a good job in top-level design and change the teaching philosophy. Modern information technology is a new type of teaching mode that organically combines information technology, information resources, human resources, big data analysis and course content to accomplish the task of teaching together. This mode is a gradual process of exploration in the actual application process. The first is to think about how to change the teaching philosophy of teachers. By organizing teachers to participate in study and training, seminars, observations, teaching and research activities, expert lectures, 
etc., teachers can gradually transform traditional teaching concepts and clarify the important role of modern information technology in assisting classroom teaching and improving classroom teaching quality. The second is to think about how to apply modern information technology in classroom teaching. The basic idea is from easiness to difficulty, highlight the demonstration effect. It is recommended to try to start from the promotion and application of the informatization teaching platform such as the Mosoink's cloud class, to highlight the classroom demonstration effects with good application results by organizing teaching reforms, classroom teaching reforms and other activities, so that teachers can understand the important role of modern information technology in changing traditional teaching models, and then systematically promote the integration of information technology, information resources, human resources, big data processing and classroom teaching content, and strive to make breakthroughs in microcurriculum and MOOC, etc. The theoretical and experimental courses of the Economics and Management specialty can use the information-based teaching platform such as the Mosoink's cloud class at different levels.

The second is to do a good job in teacher training and improve application capabilities. When formulating a teacher training plan at the beginning of each school year, it is recommended to incorporate modern information technology learning, together with professional knowledge training and high-level academic forums, into the teacher training program, and focus on supporting willing, well-grounded, and experienced key teachers and excellent teachers to learn modern information technology, in order to improve teachers' modern information technology application capabilities. Through secondary training, experience exchange meetings, professional teaching and research activities, etc., more teachers can understand the important role of modern information technology in classroom teaching and gradually change the traditional teaching concepts of teachers.

The third is to implement the application and reform the teaching model. Modern information teaching requires the support of software and hardware supporting facilities to carry out information-based teaching. In addition to using online platforms such as mobile clients, it can also create offline smart classrooms, supplemented by related software and hardware facilities to support teachers in using modern information technology to carry out teaching activities. At the same time, it is recommended to strongly support the willing, well-grounded and experienced backbone teachers and prominent teachers to learn modern information technology, and then demonstrate the learning effectiveness and introduce the latest modern information teaching methods through various forms such as experience exchange, secondary training, teaching and research conferences, and quality class competitions.

The application and practicality of the Economics and Management specialty of local applied universities are strong. A large proportion of experimental training courses are completed in the virtual simulation experiment center. Therefore, the application of modern information technology focuses on building high-level intelligent classrooms and experimental centers, optimizing education and teaching management and service platforms, pooling high-quality teaching resources, and constructing new modes of practice and education in a multi-dimensional way to reform and innovate classroom teaching models.

\section{THE COMMON PROBLEMS OF MODERN INFORMATION TECHNOLOGY IN THE APPLICATION OF CLASSROOM TEACHING OF ECONOMICS AND MANAGEMENT}

The first is the conflict between modern information technology concepts and educational concepts. The conflict between modern information technology concepts and educational concepts is mainly reflected in the role of modern information technology in the classroom teaching of Economics and Management specialty. Some teachers have narrowly defined modern information technology as a multimedia teaching method such as PPT. Its function is to replace the blackboard-writing in the classroom, which cures and limits the use of modern information technology. Some teachers rely entirely on modern information technology in classroom teaching activities, and use software or mobile client as a carrier to replace the intuitive teaching of teachers in the classroom, which separates the relationship between modern information technology and traditional classroom teaching, making them become opposites. Whether it is a substitute for blackboard-writing or a carrier for classroom content, it has not truly realized the deep integration of modern information technology and classroom teaching.

The second is the limitations of teachers' personal abilities and overall quality. Due to differences in age, professional background, and knowledge structure, some teachers lack the ability to make full use of modern information technology. On the one hand, years of teaching habits and teaching experience have smashed their thinking, which makes them feel skeptical about the emerging modern information technology; on the other hand, in the face of the increasingly profound changes in the Internet era, their cognitive and technical abilities are relatively lagging behind, which cannot satisfy their need to apply modern information technology to classroom teaching. In addition, geographical differences are also one of the limiting factors in the application of modern information technology to classroom teaching activities. Some ordinary college teachers in remote areas lack the software and hardware conditions to face the latest modern information technology, especially in comparison with first-tier cities and key institutions. Limited by subjective and objective conditions, teachers' comprehensive literacy differences constrain their use of modern information technology in the classroom teaching of Economics and Management specialty.

The third is that students lack the willingness and motivation to learn independently. The use of modern information technology in classroom teaching, in addition to basic multimedia courseware and other auxiliary teaching methods, also includes students' self-learning mode such as flipping classroom and MOOC. However, some students are unable to make full use of online resources because of the lack of awareness of active learning. Of course, similar problems exist in traditional classroom teaching. However, compared with the direct guidance of teachers and face-to-face intensive education, how to improve the enthusiasm and practicality of 
students' independent learning, so that they can enjoy the application of modern information technology to teaching, is undoubtedly worthy of our consideration.

The fourth is ignoring the advantages of the traditional classroom teaching model. The use of modern information technology in classroom teaching does not mean that teachers can get rid of the dependence on traditional teaching models, especially for Economics and Management specialty. The characteristics of this profession determine that in the teaching process, teachers must not only make full use of the achievements of modern information technology, and carry out simulation of teaching scenarios through some internships and training platforms to enhance students' comprehensive practical ability, but also rely on traditional classroom teaching to consolidate the students' basic theoretical foundation. In fact, in practice, it is easy to fall into such a misunderstanding, that is, relying entirely on the practical teaching platform or mobile client, thus neglecting the guiding role of traditional classroom teaching to students.

\section{SUGGeStions ON PROMOTING THE DEEP INTEGRATION OF MODERN INFORMATION TECHNOLOGY AND CLASSROOM TEACHING OF ECONOMICS AND MANAGEMENT}

The first is to create an environment conducive to information-based teaching. The ideal and belief is the "calcium" of the spirit. To realize the deep integration of modern information technology and classroom teaching in Economics and Management specialty, the first thing to do is to change the concept of development and adhere to the concept of innovative education and teaching reform. From the leadership of the school to the ordinary front-line teachers, they should fully recognize the important role of modern information technology in classroom teaching, pay attention to it from the mind, support it from the policy, and implement it from the action. Teachers, especially young teachers, should be encouraged to actively participate in activities such as "microcourses" and multimedia courseware production competitions, so that modern information technology can be better integrated into classroom teaching to create an environment conducive to information-based teaching.

The second is to improve the overall quality of the teachers of Economics and Management specialty. The teaching of Economics and Management specialty requires teachers to have a solid theoretical foundation and rich practical experience. They should also keep pace with the times, continuously complete knowledge change, and draw on the latest economic ideas and management experience. Therefore, to improve the overall quality of teachers should start from the following aspects: First, it is necessary to strengthen the professional theoretical basis of the teachers of the Economics and Management specialty, and to promote exchanges between teachers through large-scale discussions, academic salons and summit forums, and encourage teachers to go out to participate in training and learning, and timely absorb advanced teaching concepts, professional knowledge, emerging technologies, etc. at home and abroad. The second is to enhance teachers' ability to apply modern information technology, such as making video files, so that teachers have the comprehensive ability to promote the deep integration of modern information technology and classroom teaching; The third is to encourage teachers to participate more in the social practice of economic management, such as going to the company to work, running the company website, etc. The truth stems from practice. Only teachers can improve their own comprehensive quality to better apply it to teaching, to meet the needs of today's education and teaching reform and information technology development.

The third is to build a practical platform for classroom teaching of Economics and Management specialty. What is needed in today's era is a composite, application-oriented talent, especially for the Economics and Management specialty. The goal of talent cultivation should be more to reflect its applicability, that is, to cultivate the talents that meet the needs of the market. For teachers and students, the practical teaching activities of Economics and Management specialty are often difficult to accomplish one-time in practice, but rely more on practical teaching platforms, including business management simulation, virtual simulation operations, cross-border ecommerce online operations and many other aspects. Therefore, it is necessary to make full use of modern information technology means, not only to introduce a professional simulation operation platform, but also to introduce a comprehensive training platform, to make full use of the information development results, to achieve online breakthroughs in classroom teaching.

The fourth is to promote the deep integration of traditional classroom teaching mode and modern technology. Based on comprehensive analysis, optimized combination, teaching students in accordance with their aptitude, and serving students it is necessary to make full use of modern information technology to enrich teaching resources, improve teaching efficiency, and stimulate students' interest in learning to create an information-based teaching environment, to transform traditional teaching models, to build a theoretical and practical teaching platform that combines online and offline, to break through teaching limitations, to innovate teaching methods and teaching content, to expand teaching activities, to promote the deep integration of modern information technology and classroom teaching of Economics and Management specialty, to achieve teaching effects, and to cultivate composite and applied talents.

\section{CONCLUSION}

With the rapid development of modern information technology such as the Internet and big data with computer network as the core, this brings new opportunities and challenges to the high-quality development of higher education in China. The common practice of local application-oriented colleges and universities to integrate modern information technology into classroom teaching of Economics and Management specialty is: to do a good job in top-level design and change the teaching philosophy; to do a good job in teacher training and improve application capabilities; to implement the application and reform the teaching model. Through in-depth analysis, the problems are summarized as: the conflict between modern information technology concepts and educational concepts; the limitations of teachers' personal abilities and overall quality; that students lack the willingness 
and motivation to learn independently; ignoring the advantages of the traditional classroom teaching model. It also puts forward suggestions to create an environment conducive to information-based teaching, to improve the overall quality of the teachers of Economics and Management specialty, to build a practical platform for classroom teaching of Economics and Management specialty, and to promote the deep integration of traditional classroom teaching mode and modern technology.

\section{REFERENCES}

[1] Nie Tingting, Li Yu, Li Xiaoqiu, Wu Wei, Jing Xuezhen, Yao Haibo. Discussion on Informatization Construction of Logistics Management in Colleges and Universities [J]. Chinese \& Foreign Entrepreneurs, 2019(24):172. (in Chinese)

[2] Zhao Yan, Fan Xiaoshu. Research on the Connotation and Application of Education Informationization[J]. Journal of Tonghua Normal University, 2018, 39(02): 91-94. (in Chinese)

[3] Cao Baorong. Application of Informatization in Modern Education and Teaching[J]. Labor Security World, 2016(08): 36. (in Chinese)

[4] Quan Yuan. On the Application of Multimedia Technology in Modern Information Teaching [J]. Vocational Technology,2014(07):56. (in Chinese) 